\title{
PENGARUH FREKUENSI PEMBERIAN PAKAN PADA PENDEDERAN KE DUA IKAN LELE DUMBO YANG DIPELIHARA DI KOLAM TANAH
}

\author{
Sri Sundari*, Estu Nugroho dan Jojo Subagja \\ Balai Riset Perikanan Budidaya Air Tawar \\ *Jalan Sempur No. 1 Bogor 16154 \\ Telp.0251-8313200,e-mail:brpbat@yahoo.co.id, sri_sundari13@yahoo.co.id
}

\author{
ABSTRACT \\ Effect of Feed Frequency on Second Rearing Larvae of Catfish Culture in Earthen Pond. \\ By. Sri Sundari, Estu Nugroho and Jojo Subagja
}

\begin{abstract}
Breeding is an important part in business scale of catfish. The critical time of catfish culture is in second rearing of larvae (from 2-3 cm to 8-10 cm) due to their canibalism. The successibility of seed rearing is depend on continuesly feed reservation, including feed management. The objective of this research was to get information about feed frequency given to seed reared in earthen pond. Research was conducted using farmer's earthen pond in Pabuaran, Kemang Bogor district. Cat fish seed originated from farmer located in Bogor, with size of 2-3 cm per each and stocking density of $100 \mathrm{fish} / \mathrm{m}^{2}$. Treatments were feed frequency i.e. $2 x ; 4 x$ and $6 x$ in a day or night. Observed parameter were survival and growth rate, including water quality. Block Randomized Design of Experiment were used with two replications. Samping was conducted every 7 days. Result showed that there was statistically significant differences $(P<0.05)$ among treatment in survival rate, while no statistically differences in growth rate of seeds length and weight. Feed frequency $2 x$ at night gived the best result of survival rate and percentage of "filter selection" was up to $80 \%$ and $37.76 \%$ respectivelly.
\end{abstract}

Keywords : Feed frequency, second rearing, catfish

\begin{abstract}
ABSTRAK
Salah satu skala bisnis ikan lele yang penting adalah pembenihan. Pada pembenihan lele, masa kritis salah satunya ditemui pada tahapan pendederan kedua (dari ukuran 2-3 cm ke 8-10 cm). Keberhasilan pendederan ini sangat tergantung pada kesediaan pakan yang kontinu, sehingga dapat menekan kanibalisme yang ada. Tujuan penelitian ini yaitu untuk mendapatkan informasi frekuensi pakan yang diberikan dengan tepat pada pendederan ikan lele yang dipelihara di kolam tanah. Penelitian ini dilaksanakan di kolam tanah di daerah pabuaran, Kemang, Bogor. Ikan uji yang digunakan adalah benih ikan lele ukuran $\pm 2-3 \mathrm{~cm} / \mathrm{ekor}$, dengan kepadatan 100 ekor $/ \mathrm{m}^{2}$. Perlakuan yang diamati adalah frekuensi pemberian pakan, yaitu i) 2x, ii) 4x dan iii) 6x, baik dilakukan pada siang maupun malam hari. Secara garis besar parameter yang diamati dalam penelitian ini meliputi pertumbuhan, dan kelangsungan hidup serta sifat fisika dan kimia air. Rancangan percobaan yang digunakan adalah rancangan acak blok yaitu berupa waktu siang dan malam dengan 2 ulangan waktu. Sampling dilakukan 7 hari sekali. Hasil yang diperoleh menunjukkan adanya perbedaan yang nyata $(\mathrm{P}<0,05)$ dari perlakuan terhadap sintasan benih, namun tidak berbeda nyata pada laju pertumbuhan harian berat dan panjang benih. Pemberian pakan dengan frekuensi $2 \mathrm{x}$ pada malam hari memberikan pengaruh yang terbaik dengan sintasan mencapai $80 \%$, dengan persentase lolos saring mencapai $37.76 \%$.
\end{abstract}

Kata kunci : frekuensi pakan, pendederan 2, ikan lele

\section{PENDAHULUAN}

Budidaya lele sudah banyak dilakukan oleh masyarakat, terutama dengan semakin menjamurnya usaha warung pecel lele, khususnya di daerah sekitar Jakarta, Bogor, Depok, Tangerang dan Bekasi (Jabodetabek). Sayangnya animo yang demikian tinggi untuk berusaha, baik dari kalangan yang tadinya tidak mengenal perikanan hingga kalangan perikanan sendiri seringkali tidak dibarengi suatu strategi yang tepat sehingga seringkali harapan untuk memperoleh keuntungan dari usaha budidaya lele tinggal berupa catatan diatas kertas saja. Tidak jarang modal yang telah ditanamkan semakin menyusut bahkan menguap tidak berbekas, dan yang tinggal hanya tumpukan sisa-sisa barang perlengkapan dan hutang dari pihak lain.

Salah satu skala bisnis ikan lele yang penting adalah pembenihan. Pada pembenihan lele, masa kritis salah satunya ditemui pada tahapan pendederan kedua. Permasalahan utama pada tahap ini adalah tingkat mortalitas yang cukup tinggi, salah satunya disebabkan oleh kanibalisme. Dalam praktek dilapangan keberhasilan tertinggi pada kelangsungan hidup adalah pada taraf $30-40 \%$ (Nugroho, 2007).

Penyebab utama kanibalisme adalah adanya kekurangan pakan serta perbedaan ukuran yang 
terlampau besar. Pencegahan kanibalisme pada ikan lele dapat dilakukan dengan menyediakan pakan yang dibutuhkan pada saat yang tepat yaitu saat ikan lapar, disamping penggunaan benih ikan dengan ukuran yang seragam. Pakan dengan kadar protein $40 \%$ dengan jumlah pemberian pakan $5 \%$ per hari yang diberikan pada ikan lele ukuran 1,5 g/ekor dapat mengurangi mortalitas akibat defisiensi pakan pada skala percobaan (Suhenda, 1988).

Tujuan dari penelitian ini adalah untuk mendapatkan informasi tentang frekuensi pemberian pakan yang tepat pada pendederan ke-2 ikan lele, dalam rangka peningkatan produktifitas budidaya ikan lele.

\section{BAHAN DAN METODE}

Penelitian ini dilakukan di Kolam Tanah petani di Pabuaran, Kecamatan Kemang, Kabupaten Bogor. Ikan uji yang digunakan dalam penelitian ini yaitu ikan lele dumbo yang diperoleh dari lokasi setempat,dengan ukuran 2-3 cm/ekor.

Pakan uji berupa pelet terapung komersial (kadar protein 28-30\%) dengan diameter 2-3 mm yang diberikan sebanyak $10 \%$ bobot biomassa dalam satu harinya. Wadah pemeliharaan kolam tanah ukuran $50 \mathrm{~m}^{2}$, yang diisi air setinggi $60 \mathrm{~cm}$. Kepadatan yang digunakan adalah 100 ekor per $\mathrm{m}^{2}$.

Rancangan percobaan yang digunakan yaitu rancangan acak blok dengan 3 perlakuan dan 2 ulangan (Sudjana, 1995). Sebagai perlakuan yaitu frekuensi pemberian pakan yang berbeda. Secara lengkap perlakuan pada penelitian ini adalah sebagai berikut :

Blok 1 (siang hari) dengan perlakuan,

A. Pemberian pakan $2 \mathrm{x}$ /hari $(08,00$ dan 12.00$)$

B. Pemberian pakan $4 \mathrm{x} / \mathrm{hari}(08,00 ; 10.00 ; 12.00$ dan 14.00 )

C. Pemberian pakan $6 \mathrm{x} /$ hari $(08.00 ; 10.00 ; 12.00$; 14.00; 16.00 dan 18.00 )

Blok 2 (malam hari) dengan perlakukan,

A. Pemberian pakan $2 \mathrm{x} /$ hari (18.00 dan 19.00)

B. Pemberian pakan $4 \mathrm{x} /$ hari $(18.00 ; 19.00 ; 20.00$ dan 21.00)

C. Pemberian pakan $6 \mathrm{x} /$ hari $(18.00 ; 19.00 ; 20.00$; 21.00; 22.00 dan 23.00)

Parameter yang diamati meliputi pertumbuhan, tingkat kelangsungan hidup dan kualitas air sebagai penunjang. Pengambilan data dilakukan dengan cara sampling tiap 7 hari sekali.
Persentase benih ikan yang dapat dijual ("lolos saring", ukuran $>8-10 \mathrm{~cm}$ ) dilakukan dengan menyeleksi ikan secara individu.

Analisa data yang digunakan untuk kelangsungan hidup organisme adalah dengan menggunakan persamaan sebagai berikut :

$$
\mathrm{S}=(\mathrm{Nt} / \mathrm{No}) \times 100 \%
$$

(Zonnevald, et al., 1991)

Dimana,

$\mathrm{S}=$ Sintasan

$\mathrm{Nt}=$ Jumlah benih pada akhir penelitian

No $=$ Jumlah benih pada awal penelitian

Sedangkan laju pertumbuhan harian individu baik berat maupun panjang dihitung berdasarkan National Research Council (1983) sebagai berikut :

Alpha $=\left((\mathrm{Wt} / \mathrm{Wo})^{\mathrm{t}}-1\right) \times 100 \%$

Dimana,

Alpha = Laju pertumbuhan harian

$\mathrm{Wt}=$ Bobot akhir rata-rata $(\mathrm{g})$ atau panjang akhir rata- $\mathrm{rata}(\mathrm{cm})$

Wo = Bobot awal rata-rata (g) atau panjang awal rata-rata $(\mathrm{cm})$

Persentase ikan yang "lolos saring" di hitung dengan persamaan sebagai berikut:

$\mathrm{P}=(\mathrm{JLS} / \mathrm{JT}) \mathrm{X} 100 \%$

Dimana,

$\mathrm{P} \quad=$ Persentase lolos saring

JLS = Jumlah benih lolos saring

JT = Jumlah total benih pada saat panen

\section{HASIL DAN BAHASAN}

Derajat kelangsungan hidup atau sintasan benih ikan lele yang dipelihara pada pendederan $2 \mathrm{di}$ kolam tanah bervariasi, nilai rataan tertinggi terdapat pada perlakuan frekuensi $2 \mathrm{x}$ blok malam hari $(73,16 \%)$ dan yang terendah pada perlakuan frekuensi 4x blok siang hari $(28,97 \%)$ (Tabel 1).

Terdapat perbedaan secara statistik pada taraf $\mathrm{P}<0,05$ antara perlakuan frekuensi pemberian pakan siang hari yaitu antara frekuensi pemberian $2 x$ dengan frekuensi pemberian 4x dan 6x, namun tidak berbeda antara perlakuan pada pemberian di malam hari. Perbedaan secara statistik juga teramati antar blok siang dan malam hari. Secara umum, sintasan benih yang diberi pakan pada malam hari 
mempunyai nilai yang lebih baik dibandingkan benih yang diberi pakan siang hari.

Fenomena perbedaan sintasan antar benih yang diberi pakan pada blok siang dan malam hari dapat dipahami karena ikan lele merupakan ikan nocturnal yaitu ikan yang aktif pada malam hari (Effendi, 1985). Dengan memberikan pakan yang tepat pada saat dibutuhkan maka akan mengurangi kemungkinan terjadinya kanibalisme antar sesamanya. Menurut hasil pengamatan Sutarmat dkk (2002), ikan kerapu bebek yang diberi makan satu kali sehari mempunyai pertumbuhan yang relatif lebih lambat $(2,03 \%$ /hari) daripada ikan yang diberi pakan 2, 3 dan 4 kali sehari masing-masing 2,79; 2,89 dan $2,75 \% /$ hari.

Hal yang menarik adalah sintasan benih yang diberi pakan $2 x$, baik siang dan malam hari, lebih tinggi dibandingkan benih dengan frekuensi pemberian pakan lainnya. Keadaan ini berlawanan dengan pendapat umum di kalangan pembudidaya tentang semakin baik jika pemberian pakan dilakukan lebih sering. Lovell (2002) menjelaskan bahwa untuk benih ukuran 3-5 g per ekor maka pemberian pakan sebanyak 1-2 x setiap hari telah mencukupi kebutuhan benih akan protein. Pemberian pakan akan tergantung antara lain pada kualitas air dan temperatur. Kemungkinan yang terjadi adalah jumlah pakan yang diberikan pada satu kali pemberian pada perlakuan frekuensi pemberian $2 \mathrm{x}$ adalah cukup dan tepat saat dibutuhkan benih ikan lele dibandingkan jumlah pada frekuensi pemberian pakan yang lainnya. Lee, S. M et.al. (2000) melakukan percobaan terhadap ikan Korean Rock Fish, bahwa pertambahan bobot dan tingkat konsumsi pakan juvenil Korean rockfish (Sebastes schlegeli) dipengaruhi oleh frekuensi pemberian pakan $(\mathrm{P}<0,05)$. Ikan yang diberi pakan pelet kering dan pelet basah satu kali sehari dan dua kali sehari pertambahan bobot dan tingkat konsumsi pakannya berbeda nyata lebih tinggi dibandingkan dengan ikan yang diberi pakan satu kali tiap dua hari.

Jika kepraktisan dan kemudahan yang menjadi pertimbangan pembudidaya maka frekuensi pemberian pakan $2 \mathrm{x}$ pada malam hari merupakan alternatif yang terbaik dalam manajemen pemberian pakan pada pendederan 2 benih ikan lele. Satu alternatif yang juga perlu di coba adalah kombinasi antara $2 \mathrm{x}$ pemberian pakan pada siang hari dan $2 \mathrm{x}$ pemberian pakan pada malam hari.

Setiawan dan A. Riyadi (2009) menyimpulkan bahwa benih ikan lele memberikan respon pertumbuhan yang berbeda terhadap perbedaan ransum harian. Relasi pertumbuhanransum harian memberikan informasi parameter- parameter ransum maksimal ( $\left.\mathrm{R}_{\text {maks. }}\right) 45,21 \%$, ransum optimal $\left(\mathrm{R}_{\mathrm{opt}}\right)$ 18,31\%, dan ransum pemeliharaan ( $\mathrm{R}_{\text {maint. }}$ ) 3,88\% bobot badan kering per hari yang secara berturut-turut menghasilkan laju pertumbuhan maksimal $\left(\mathrm{G}_{\text {maks. }}\right) 27,32 \%$, laju pertumbuhan optimal $\left(\mathrm{G}_{\text {opt. }}\right) 15,77 \%$ dan laju pertumbuhan nol $\left(\mathrm{G}_{0}\right)$.

Persentase jumlah ikan yang "lolos saring" juga bervariasi, nilai rataan tertinggi pada perlakuan frekuensi pemberian pakan $2 \mathrm{x}$ pada blok malam hari $(37,76 \%)$ sedangkan yang terendah terdapat pada frekuensi pemberian pakan $4 \mathrm{x}$ pada blok siang hari $(14,77 \%)$ (Tabel 2).

Secara statistik terdapat perbedaan yang nyata $(\mathrm{P}<0,05)$ antar perlakuan, baik pada blok siang maupun malam hari, namun tidak berbeda nyata antar blok. Perbedaan terjadi antar frekuensi pemberian pakan $2 \mathrm{x}$ dengan $4 \mathrm{x}$ dan $6 \mathrm{x}$ serta antar frekuensi $4 \mathrm{x}$ dengan $6 \mathrm{x}$ pada siang hari. Sedangkan pada malam hari perbedaan terjadi antar perlakuan frekuensi $2 \mathrm{x}$ dengan $4 \mathrm{x}$ dan $6 \mathrm{x}$ namun tidak berbeda nyata antar perlakuan $4 x$ dan $6 x$. Secara umum, pemberian pakan pada malam hari menghasilkan benih dengan ukuran "lolos saring" yang lebih banyak dibandingkan pemberian pakan pada siang hari yaitu sebesar 2,56\%.

Keadaan di atas mengindikasikan bahwa pemberian pakan pada malam hari pada ikan lele sebagai hewan nocturnal adalah tepat. Dengan keseragaman yang lebih tinggi pada perlakuan frekuensi pemberian pakan $2 x$ baik pada siang dan malam hari dapat mengurangi kanibalisme yang mungkin terjadi di budidaya ikan lele. Sutarmat dkk (2004) menyimpulkan bahwa perlakuan ikan kerapu bebek berukuran $10-50 \mathrm{~g}$ dan 50-150 g yang diberi pakan sebanyak 3 kali sehari dan 2 kali sehari menunjukkan pertumbuhan yang tinggi dan konversi pakan yang rendah dan berbeda nyata dibanding perlakuan lainnya $(\mathrm{P}<0,05)$.

Rataan laju pertumbuhan harian panjang tubuh ikan lele di pendederan 2 bervariasi antara $4,23 \%$ (frekuensi 6x malam hari) hingga 6,25\% (frekuensi 2x siang hari) (Tabel 3).

Secara statistik tidak terdapat perbedaan yang nyata antar perlakuan frekuensi pemberian pakan pada siang dan malam hari. Perbedaan nyata $(\mathrm{P}<0,05)$ hanya terjadi antar blok siang dan malam hari. Secara umum pertumbuhan harian panjang individu ikan lele pada pemberian pakan siang hari $(5,87 \%)$ lebih tinggi dibandingkan pada benih lele dengan pemberian pakan pada malam hari $(4,44 \%)$.

Rataan laju pertumbuhan harian bobot ikan lele pada pendederan 2 juga bervariasi, antara $14,23 \%$ (frekeunsi 6x malam hari) hingga 19,10\% (frekuensi 2x siang hari) (Tabel 4). 
Secara statistik perbedaan yang nyata $(\mathrm{P}<$ $0,05)$ hanya diamati pada benih lele antar blok siang dan malam, namun tidak berbeda nyata antar perlakuan dalam blok. Secara umum, rataan laju pertumbuhan pada malam hari $(14,95 \%)$ lebih rendah dibandingkan dengan rataan laju pertumbuhan pada siang hari $(17,62 \%)$.

Fenomena ini menunjukkan bahwa adanya kemungkinan hubungannya dengan kandungan oksigen terlarut, dimana siang hari lebih banyak dibandingkan pada malam hari sehingga proses metabolisme ikan lebih baik pada siang hari (Lovell, 2002). Kemungkinan pakan pada malam hari lebih banyak terserap dan digunakan sebagai energi untuk beraktivitas termasuk saat berebut pakan, dimana ikan lele termasuk hewan nocturnal. Sedangkan jika pada siang hari, pakan sebagian besar disimpan sebagai cadangan, dimana pada siang hari mereka tidak banyak bergerak karena tidak ada aktivitas pemberian pakan. Tampak jelas pada grafik pertumbuhan panjang dan berat tubuh ikan lele di pendederan 2 (Gambar 1).

Nilai kisaran kualitas air yang ada pada akhir penelitian tertera pada Tabel 5). Nilai parameter ammonia masih dalam taraf layak untuk budidaya ikan lele.

Tabel 1. Sintasan benih lele di pendederan 2 kolam tanah (\%)

\begin{tabular}{|c|c|c|c|c|c|c|c|c|c|}
\hline \multirow{2}{*}{ Ulangan } & & \multicolumn{4}{|c|}{ Siang Hari } & \multicolumn{4}{|c|}{ Malam Hari } \\
\hline & & $\mathrm{x} 2$ & $\mathrm{x} 4$ & $x 6$ & rataan & $\mathrm{x} 2$ & $\mathrm{x} 4$ & $\mathrm{x} 6$ & rataan \\
\hline & 1 & 49,70 & 42,60 & 47,92 & & 66,20 & 65,90 & 76,50 & \\
\hline & 2 & 44,28 & 15,34 & 16,60 & & 80,12 & 73,32 & 60,30 & \\
\hline rataan & & 46,99 & 28,97 & 32,26 & 36,07 & 73,16 & 69,61 & 68,4 & 70,39 \\
\hline
\end{tabular}

Tabel 2. Persentase benih ukuran "lolos saring" (\%)

\begin{tabular}{|c|c|c|c|c|c|c|c|c|c|}
\hline \multirow{2}{*}{ Ulangan } & & \multicolumn{4}{|c|}{ Siang Hari } & \multicolumn{4}{|c|}{ Malam Hari } \\
\hline & & $\mathrm{x} 2$ & $\mathrm{x} 4$ & $x 6$ & rataan & $\mathrm{x} 2$ & $\mathrm{x} 4$ & $x 6$ & rataan \\
\hline & 1 & 30,7 & 12,58 & 28,63 & & 38,07 & 28,22 & 29,15 & \\
\hline & 2 & 38,39 & 16,95 & 29,52 & & 37,44 & 15,55 & 23,71 & \\
\hline rataan & & 34,55 & 14,77 & 29,07 & 26,13 & 37,76 & 21,89 & 26,43 & 28,69 \\
\hline
\end{tabular}

Tabel 3. Laju permbuhan harian (panjang) benih ikan lele di pendederan 2

\begin{tabular}{cccccccccc}
\hline \multirow{2}{*}{ Ulangan } & \multicolumn{4}{c}{ Siang Hari } & \multicolumn{5}{c}{ Malam Hari } \\
\cline { 2 - 9 } & & $\mathrm{x} 2$ & $\mathrm{x} 4$ & $\mathrm{x} 6$ & rataan & $\mathrm{x} 2$ & $\mathrm{x} 4$ & $\mathrm{x} 6$ & rataan \\
\hline & $\mathrm{u} 1$ & 5,90 & 6,15 & 6,40 & & 4,60 & 4,60 & 4,18 \\
& $\mathrm{u} 2$ & 6,60 & 5,06 & 5,10 & & 4,30 & 4,69 & 4,27 \\
& & & & & & & & & \\
\hline \multirow{2}{*}{ rataan } & 6,25 & 5,605 & 5,75 & 5,87 & 4,45 & 4,645 & 4,225 & 4,44 \\
\hline
\end{tabular}


Tabel 4. Laju pertumbuhan harian (bobot) benih ikan lele di pendederan 2

\begin{tabular}{|c|c|c|c|c|c|c|c|c|c|}
\hline \multirow{2}{*}{ Ulangan } & & \multicolumn{4}{|c|}{ Siang Hari } & \multicolumn{4}{|c|}{ Malam Hari } \\
\hline & & $\mathrm{x} 2$ & $\mathrm{x} 4$ & $\mathrm{x} 6$ & rataan & $\mathrm{x} 2$ & $\mathrm{x} 4$ & $x 6$ & rataan \\
\hline & $\mathrm{u} 1$ & 17,6 & 17,98 & 19,32 & & 15,05 & 15,03 & 13,83 & \\
\hline & $\mathrm{u} 2$ & 20,59 & 15,07 & 15,14 & & 14,17 & 17,01 & 14,62 & \\
\hline rataan & & 19,1 & 16,53 & 17,23 & 17,62 & 14,61 & 16,02 & 14,23 & 14,95 \\
\hline
\end{tabular}

Tabel 5. Nilai kisaran kualitas air di kolam pendederan ikan lele

\begin{tabular}{lccccc}
\hline & \multicolumn{5}{c}{ Parameter } \\
\cline { 2 - 6 } Perlakuan & $\mathrm{pH}$ & $\begin{array}{c}\text { Suhu } \\
\left({ }^{\circ} \mathrm{C}\right)\end{array}$ & $\begin{array}{c}\text { Nitrat } \\
(\mathrm{ppm})\end{array}$ & $\begin{array}{c}\text { Nitrit } \\
(\mathrm{ppm})\end{array}$ & Amonia (ppm) \\
\hline $\mathrm{nyyyyy}$ x2 & $7,76-7,81$ & $30,6-30,7$ & $0,101-0,170$ & $0,946-1,065$ & $0,321-0,336$ \\
$\mathrm{x} 4$ & $7,71-7,80$ & $30,7-30,9$ & $0,06-0,143$ & $0,868-1,274$ & $0,261-0,352$ \\
$\mathrm{x} 6$ & $7,40-7,53$ & $30,7-31,0$ & $0,119-0,123$ & $1,231-1,317$ & $0,096-0,149$ \\
\hline
\end{tabular}

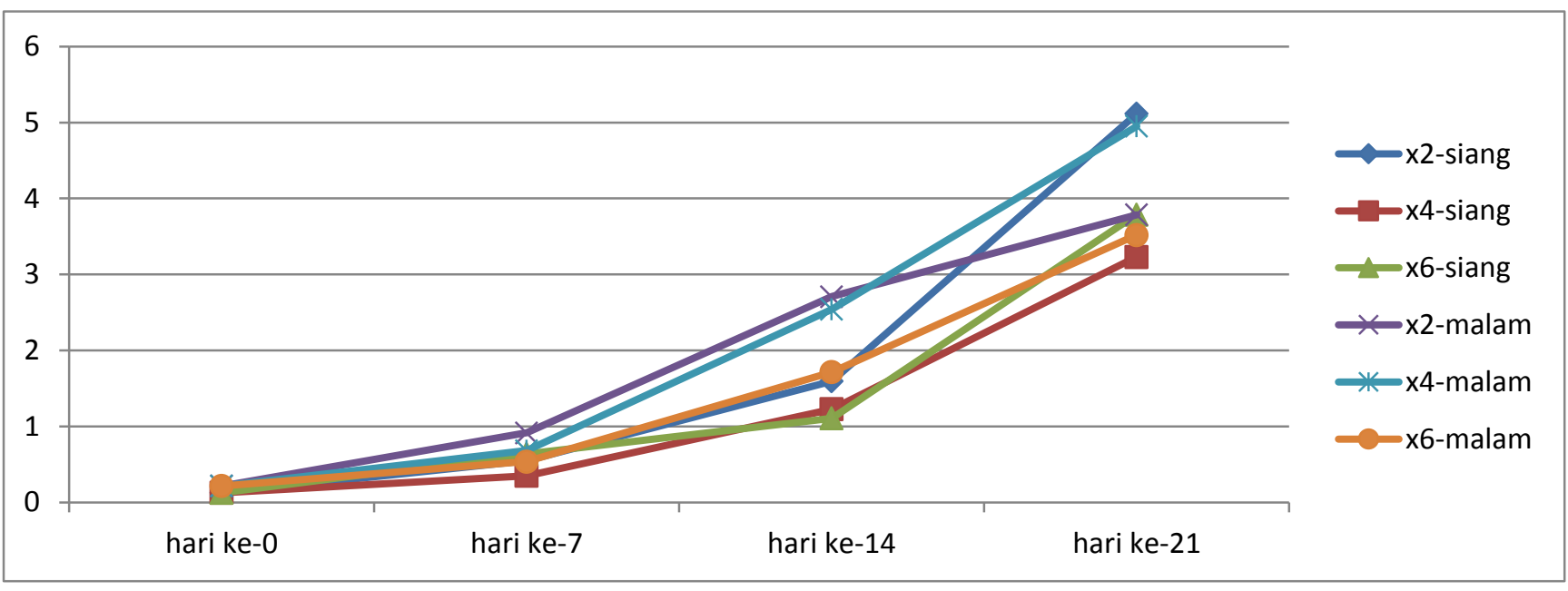

Gambar 1. Pertumbuhan bobot badan (gram) benih lele di pendederan 2

\section{KESIMPULAN}

Frekuensi pemberian pakan 2x pada malam hari memberikan sintasan tertinggi pada benih ikan lele yang dipelihara di kolam tanah hingga $80 \%$ dan memberikan persentase terbesar ukuran ikan yang lolos saring sebesar $37,76 \%$.

\section{UCAPAN TERIMA KASIH}

Penelitian ini terselenggara dengan bantuan dana dari DIKNAS tahun anggaran 2009 melalui program kerjasama HIBAH PENELITIAN BAGI PENELITI DAN PEREKAYASA dengan DKP. 


\section{DAFTAR PUSTAKA}

Effendi, I. 1985. Fisiologi Ikan. Kuliah Mata Ajaran Fisiologi. Fakultas Perikanan IPB.

Lee, S. M., et. al. 2000. Effects of feeding frequency and dietary moisture content on growth, body composition and gastric evacuation of juvenile Korean rockfish (Sebastes schlegeli). Aquaculture 187 : 399-409.

Lovell, R. T. 2002. Diet and Fish husbandry. In. Fish Nutrition third edition. Ed. by J. E. Halver and R. W. Hardy. Academic Press. 703-754p

Nugroho, E. 2007. Kiat agribisnis lele. Penebar Swadaya. Jakarta. 73p.

National Research Council. 1983. Nutrient requirement of warm water fishes and shellfish. National Academy of Science. Washington D.C. 102 p.

Setiawan, A. dan A. Priyadi. 2009. Relasi pertumbuhan dan ransum harian pada benih ikan lele (Clarias batrachus L.). Jurnal Riset Akuakultur Vol.4 No. 3 hal. 341-347.

Sudjana. 1995. Desain dan analisis eksperimen. Edisi IV. Tarsito. Bandung.
Suhenda, N. 1988. Pertumbuhan benih ikan lele ( $C$. batrachus) yang mendapat ransum dengan kadar protein dan energy yang berbeda. Bulletin Penelitian Perikanan Darat Vol. 7 No. 2.23 hal.

Sutarmat, T., at. al. 2004. Studi frekuensi pemberian pakan ikan kerapu bebek (Cromileptes altivelis) dengan ukuran yang berbeda. Jurnal penelitian perikanan Indonesia volume 10, No.1.

Sutarmat, T., at. al. 2002. Pendederan benih kerapu bebek (Cromileptes altivelis) dalam keramba jaring apung dengan frekuensi pemberian pakan yang berbeda. Prosiding seminar ribtek kelautan perikanan. Hal 170-174.

Zonneveld, N., E. A. Huisman dan J. H. Boon. 1991. Prinsip - prinsip budidaya ikan. PT. Gramedia Pustaka Utama. Jakarta. 100 hal. 